\title{
Dissociation of 4-Chloro-4'-Aminodiphenylsulfone
}

\author{
Eliza beth E. Sager and Fleur C. Byers
}

\begin{abstract}
The ultraviolet absorption spectra of 4-chloro-4'-aminodiphenylsulfone has been determined. The dissociation may be considered as the acidic dissociation of the ammonium ion which is formed with the addition to the base of hydrogen ion from an acid such as hydrochloric acid. Spectrophotometric measurements of several concentrations of 4-chloro-4'aminodiphenylsulfone at various known hydrogen-ion concentrations were made at $25^{\circ} \mathrm{C}$, from which the values $p K_{c}$, based upon the concentrations, were determined. From these, the value of $p K_{a}$ was derived. At $25^{\circ} \mathrm{C}, p K_{a}$ is 1.38 , which corresponds to a value of 0.042 mole per liter for $K_{a}$. The activity coefficient terms may be expressed simply as a linear function of the ionic strength. Spectrophotometric measurements were also made at $15^{\circ}, 20^{\circ}$, $25^{\circ}, 30^{\circ}$, and $35^{\circ} \mathrm{C}$ on certain solutions in order to calculate the heat of dissociation. It was found to be 21,000 joules $\mathrm{deg}^{-1}$ mole $^{-1}$. The basic dissociation constant, $K_{b}$, is $2.4 \times 10^{-13}$, or $p K_{b}$ is 12.62 .
\end{abstract}

\section{Introduction}

Derivatives of diphenylsulfone, such as dihydroxy diphenylsulfone and diaminodiphenylsulfone, have attracted attention as intermediates particularly in the synthesis of biocides. Heymann and Fieser have prepared many derivatives of the parent compound 4,4'-diaminodiphenylsulfone in their research studies of antimalarials [1]. ${ }^{1}$ They kindly supplied us with several compounds which they had prepared and we have used them in our studies of the spectral absorbance of organic compounds. The diphenylsulfones are almost insoluble in water, but solutions of the order of $10^{-4}$ to $10^{-5}-M$ may be obtained which are suitable for spectrophotometric measurements. Derivatives of diphenylsulfone absorb in the ultraviolet portion of the spectrum and measurements in this region afford a satisfactory means of observing some aspects of their chemical behavior.

Compounds of similar molecular structure, specifically benzophenone, 4-aminobenzophenone, and 4,4'diaminobenzophenone have already been studied at the Bureau. Reports have been published including the ultraviolet spectra, dissociation reactions, and the effect of temperatures in the range of $10^{\circ}$ to $40^{\circ} \mathrm{C}$ upon the spectra $[2,3,4]$. This paper deals specifically with the acidic dissociation of the ammonium ion of 4-chloro-4'-aminodiphenylsulfone at $25^{\circ} \mathrm{C}$, and with the effect of temperature upon its dissociation.

\section{Experimental Procedure}

\subsection{Materials}

* 4-Chloro-4'-aminodiphenylsulfone is a white crystalline material that melts at 183 to $187^{\circ} \mathrm{C}$ [1]. The solubility in water is about $20 \mathrm{mg} /$ liter at $25^{\circ} \mathrm{C}$.

Hydrochloric acid of reagent grade was used to adjust the hydrogen-ion concentration of most of the solutions. Standardized sodium hydroxide, free from carbonate, was also employed. Conductivity water was used to prepare the stock solutions and for subsequent dilutions.

\footnotetext{
1 Figures in brackets indicate the literature references at the end of this paper.
}

\subsection{Equipment}

A model DU Beckman spectrophotometer was equipped with a specially designed cell compartment with sides, bottom, and removable top which were water-jacketed. The temperature within the cell compartment was controlled by circulating water from a water bath controlled by a thermostat.

A commercial glass-electrode assembly was used to make $p \mathrm{H}$ measurements of all solutions.

All equipment except the water bath was housed in a constant-temperature room at $25^{\circ} \mathrm{C}$. Solutions were prepared and stored in this room.

\section{Calculation of Dissociation Constants From Spectral Absorbance Data}

\subsection{Absorbance Measurements}

4-Chloro-4'-aminodiphenysulfone exists as the base in water. When hydrogen ion from an acid such as hydrochloric acid is added, it is transformed to the ionic state, thus

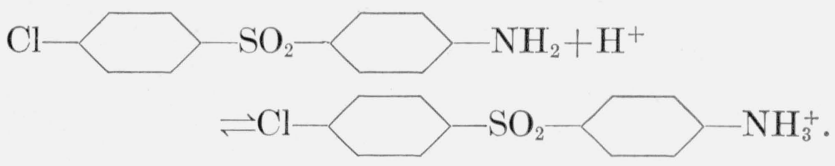

The reaction may be simply represented as the acidic dissociation of the ammonium ion, namely, $\mathrm{RNH}_{3}^{+} \rightleftharpoons \mathrm{RNH}_{2}+\mathrm{H}^{+}$.

According to the law of absorption, at any given wavelength,

$$
\text { Molar absorbance }=A / b M
$$

in which $A$ is the absorbance of the sample being measured ( $-\log _{10}$ transmittancy), $b$ is the depth of solution in centimeters through which the radiant energy passes, and $M$ is the molar concentration of the absorbing compound. The quantity $A / b M$ is frequently called molecular extinction coefficient, and is represented by the symbol $\epsilon$. Molar absorbance is expressed in liters mole $\mathrm{cm}^{-1}$. 


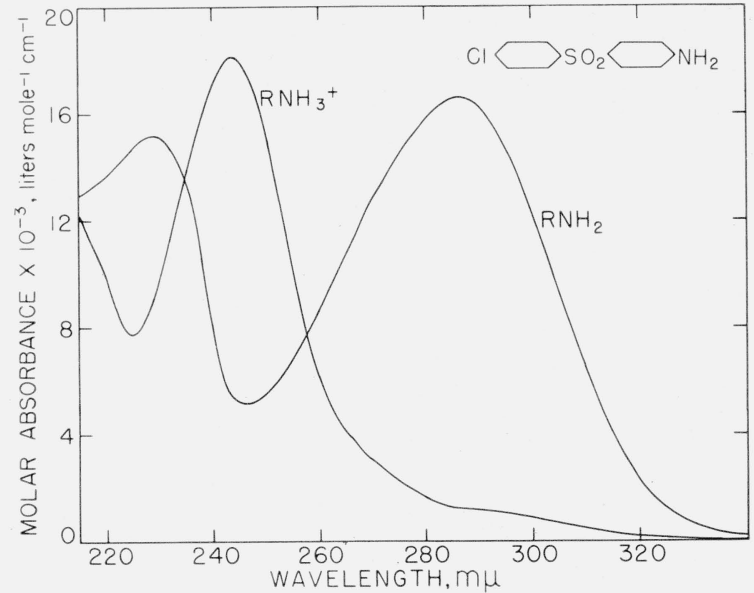

Figure 1. Molar absorbance of 4-chloro-4'-aminodiphenylsulfone in the molecular state $\left(\mathrm{RNH}_{2}\right)$ and the ionic state $\left(\mathrm{RNH}_{3}^{+}\right)$.

The values of molar absorbance for the molecular and the ionic states of 4-chloro-4'-aminodiphenylsulfone are shown in figure 1. The curve marked $\mathrm{RNH}_{2}$ shows maximum molar absorbance of about 17,000 liters mole $\mathrm{cm}^{-1}$ at a wavelength of $286 \mathrm{~m} \mu$. The compound is transformed to the ionic state, $\mathrm{RNH}_{3}^{+}$, in a solution of hydrochloric acid, 0.05-M, and exhibits maximum molar absorbance of about 18,000 liters mole $\mathrm{cm}^{-1}$ at a wavelength of $244 \mathrm{~m} \mu$.

Observations were made on four different series of solutions of 4-chloro- $4^{\prime}$-aminodiphenylsulfone at various stages of the dissociation at known hydrogenion concentrations. A typical series is shown in figure 2. Absorbance values corresponding to experimental transmittancy values of a $3.75 \times 10^{-5}-M$ solution of the diphenylsulfone in 1-cm absorption cells are plotted as a function of wavelength. Curve 1 represents $\mathrm{RNH}_{2}$ in water, and curve $15, \mathrm{RNH}_{3}^{+}$ in $0.5-M$ hydrochloric acid. The intermediate stages in the dissociation are shown in curves 2 to 14 inclusive. The two well-defined isosbestic points at 234.8 and $258 \mathrm{~m} \mu$ not only indicate purity of the compound but show that only one reaction, that of dissociation, is taking place. The amounts of each species of the partially dissociated compound are proportional to their absorbance values (curves 1 and 15). The absorbance data may therefore be used to calculate the percentage dissociated into ions. Let $\alpha$ represent this percentage, which can be calculated from the following equation:

$$
\alpha=\frac{A_{\mathrm{RNH}_{2}}-A_{\alpha}}{A_{\mathrm{RNH}_{2}}-A_{\mathrm{RNH}_{3}^{+}}^{+}}
$$

in which $A_{\mathrm{RNH}_{2}}$ is the absorbance of the molecular species, $A_{\alpha}$ is the absorbance at any dissociation step, and $A_{\mathrm{RNH}_{3}}^{+}$is the absorbance of the ionic species.

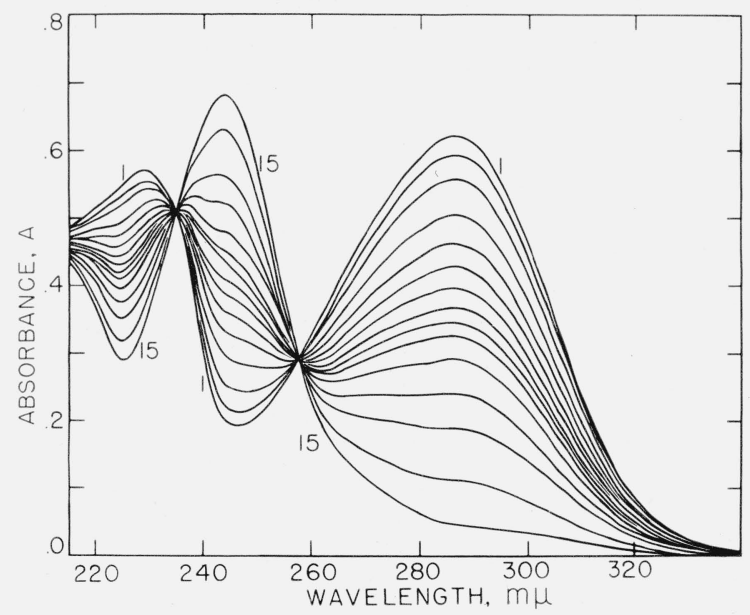

Figure 2. Absorbance values of 4-chloro-4'-aminodiphenylsulfone at various hydrogen-ion concentrations representing its dissociation $\left(3.75 \times 10^{-5}-M\right.$ in $1-\mathrm{cm}$ absorption cells).

\subsection{Calculation of Concentration Constants}

The concentration constant, $K_{c}$, can be calculated according to the equation

$$
K_{c}=\frac{\left[\mathrm{RNH}_{2}\right]\left[\mathrm{H}^{+}\right]}{\left[\mathrm{RNH}_{3}^{+}\right]},
$$

in which $\left[\mathrm{RNH}_{2}\right],\left[\mathrm{H}^{+}\right]$, and $\left[\mathrm{RNH}_{3}^{+}\right]$are the concentrations of the free base, hydrogen ion, and the ionic species, respectively. Since $\alpha$ represents the degree of dissociation into ions, $1-\alpha$ is the fraction of the remaining base, and we have the familiar equation

$$
K=\frac{(1-\alpha)\left[\mathrm{H}^{+}\right]}{\alpha} .
$$

It is advisable to observe the resulting $\alpha$ values for variations or trends in the calculated values. In this case it is obvious that best results can be obtained from about 280 to $292 \mathrm{~m} \mu$. Calculated $\alpha$ values at nine wavelengths are given in table 1.

Average values of $\alpha$ are used to calculate each ratio of $(1-\alpha) / \alpha$ at the various hydrochloric acid concentrations as shown in table 2 . The corrected hydrogen-ion concentration is that of the hydrochloric acid less the amount of hydrogen ion used for the dissociation step corresponding to $\alpha$. This figure multiplied by the ratio $(1-\alpha) / \alpha$ gives the concentration constant, $K_{c}$. The negatives of the logarithms of the constants, or $p K_{c}$ values, are then found.

\subsection{Estimation of $p K_{a}$ at $25^{\circ} \mathrm{C}$}

The true thermodynamic constant, $K_{a}$, is calculated by eq (5), 
TABLE 1. Absorbance values of 4 -chloro-4'-aminodiphenylsulfone $\left(3.747 \times 10^{-5}-M\right)$ and calculated values of $\alpha$ at several wave lengths

\begin{tabular}{|c|c|c|c|c|c|c|c|c|c|c|}
\hline \multirow{2}{*}{ Solution } & \multirow{2}{*}{ Absorbance and $\alpha$} & \multicolumn{9}{|c|}{ Wavelength $(\mathrm{m} \mu)$} \\
\hline & & 280 & 282 & 284 & 285 & 286 & 287 & 288 & 290 & 292 \\
\hline $1 \ldots$ & $\left\{\begin{array}{l}A_{-} \\
\alpha_{-}\end{array}\right.$ & $\begin{array}{l}0.5884 \\
.000\end{array}$ & 0.6056 & 0.6162 & 0. 6198 & 0.6216 & 0.6216 & 0.6198 & 0.6091 & 0.5935 \\
\hline $2 \ldots$ & $\left\{\begin{array}{l}A_{\ldots} \\
\alpha_{\ldots}\end{array}\right.$ & $\begin{array}{l}.5654 \\
.044\end{array}$ & $\begin{array}{l}.5817 \\
.043\end{array}$ & $\begin{array}{l}.5901 \\
.046\end{array}$ & $\begin{array}{l}.5943 \\
.045\end{array}$ & $\begin{array}{l}.5943 \\
.048\end{array}$ & $\begin{array}{l}.5943 \\
.047\end{array}$ & $\begin{array}{l}.5918 \\
049\end{array}$ & $\begin{array}{l}.5850 \\
.043\end{array}$ & $\begin{array}{l}.5686 \\
.045\end{array}$ \\
\hline $3 \ldots$ & $\left\{\begin{array}{l}A \ldots \\
\alpha \ldots\end{array}\right.$ & $\begin{array}{l}.5339 \\
.104\end{array}$ & $\begin{array}{l}.5452 \\
.110\end{array}$ & $\begin{array}{l}.5544 \\
.109\end{array}$ & $\begin{array}{l}.5575 \\
.109\end{array}$ & $\begin{array}{l}.5575 \\
.112\end{array}$ & $\begin{array}{l}.5575 \\
111\end{array}$ & $\begin{array}{l}.5560 \\
.111\end{array}$ & $\begin{array}{l}.5498 \\
.105\end{array}$ & $\begin{array}{l}.5331 \\
.110\end{array}$ \\
\hline $4 \ldots$ & $\left\{\begin{array}{l}A_{-} \\
\alpha_{-}\end{array}\right.$ & $\begin{array}{l}.4828 \\
.201\end{array}$ & $\begin{array}{l}.4948 \\
.201\end{array}$ & $\begin{array}{l}.5045 \\
.197\end{array}$ & $\begin{array}{l}.5059 \\
.199\end{array}$ & $\begin{array}{l}.5072 \\
.199\end{array}$ & $\begin{array}{l}.5072 \\
.199\end{array}$ & $\begin{array}{l}.5059 \\
.199\end{array}$ & $\begin{array}{l}.4962 \\
.200\end{array}$ & $\begin{array}{l}.4828 \\
.201\end{array}$ \\
\hline $5 \ldots$ & $\left\{\begin{array}{l}A_{\ldots} \\
\alpha_{\ldots}\end{array}\right.$ & $\begin{array}{l}.4443 \\
.274\end{array}$ & $\begin{array}{l}.4541 \\
.275\end{array}$ & $\begin{array}{l}.4609 \\
.274\end{array}$ & $\begin{array}{l}.4622 \\
.276\end{array}$ & $\begin{array}{l}.4641 \\
.274\end{array}$ & $\begin{array}{l}.4622 \\
.277\end{array}$ & $\begin{array}{l}.4609 \\
.277\end{array}$ & $\begin{array}{l}.4541 \\
.275\end{array}$ & $\begin{array}{l}.4413 \\
.276\end{array}$ \\
\hline $6 \ldots$ & $\left\{\begin{array}{l}A_{\ldots} \\
\alpha_{\ldots}\end{array}\right.$ & $\begin{array}{l}.4123 \\
.335\end{array}$ & $\begin{array}{l}.4202 \\
.337\end{array}$ & $\begin{array}{l}.4260 \\
.336\end{array}$ & $\begin{array}{l}.4283 \\
.335\end{array}$ & $\begin{array}{l}.4295 \\
.335\end{array}$ & $\begin{array}{l}.4295 \\
.334\end{array}$ & $\begin{array}{l}.4260 \\
.338\end{array}$ & $\begin{array}{l}.4202 \\
.335\end{array}$ & $\begin{array}{l}.4078 \\
.337\end{array}$ \\
\hline $7 \ldots$ & $\left\{\begin{array}{l}A_{-} \\
\alpha_{\ldots}\end{array}\right.$ & $\begin{array}{l}.3830 \\
.391\end{array}$ & $\begin{array}{l}.3893 \\
.393\end{array}$ & $\begin{array}{l}.3958 \\
.389\end{array}$ & $\begin{array}{l}.3969 \\
.390\end{array}$ & $\begin{array}{l}.3969 \\
.392\end{array}$ & $\begin{array}{l}.3969 \\
.391\end{array}$ & $\begin{array}{l}.3947 \\
.392\end{array}$ & $\begin{array}{l}.3893 \\
.390\end{array}$ & $\begin{array}{l}.3778 \\
.392\end{array}$ \\
\hline $8 \ldots$ & $\left\{\begin{array}{l}A \ldots \ldots \\
\alpha \ldots\end{array}\right.$ & $\begin{array}{l}.3575 \\
.439\end{array}$ & $\begin{array}{l}.3635 \\
.440\end{array}$ & $\begin{array}{l}.3675 \\
.439\end{array}$ & $\begin{array}{l}.3686 \\
.439\end{array}$ & $\begin{array}{l}.3686 \\
.441\end{array}$ & $\begin{array}{l}.3686 \\
.440\end{array}$ & $\begin{array}{l}.3675 \\
.440\end{array}$ & $\begin{array}{l}.3615 \\
.439\end{array}$ & $\begin{array}{l}.3507 \\
.441\end{array}$ \\
\hline $9 \ldots$ & $\left\{\begin{array}{l}A \ldots \\
\alpha\end{array}\right.$ & $\begin{array}{l}.3372 \\
.478\end{array}$ & $\begin{array}{l}.3410 \\
.481\end{array}$ & $\begin{array}{l}.3458 \\
.478\end{array}$ & $\begin{array}{l}.3468 \\
.478\end{array}$ & $\begin{array}{l}.3468 \\
.479\end{array}$ & $\begin{array}{l}.3468 \\
.478\end{array}$ & $\begin{array}{l}.3449 \\
.479\end{array}$ & $\begin{array}{l}.3391 \\
.478\end{array}$ & $\begin{array}{l}3298 \\
.479\end{array}$ \\
\hline $10 \ldots$ & $\left\{\begin{array}{l}A \ldots \\
\alpha \ldots\end{array}\right.$ & $\begin{array}{l}.3179 \\
.515\end{array}$ & $\begin{array}{l}.3224 \\
.514\end{array}$ & $\begin{array}{l}.3261 \\
.512\end{array}$ & $\begin{array}{l}.3270 \\
.512\end{array}$ & $\begin{array}{l}.3270 \\
.513\end{array}$ & $\begin{array}{l}.3270 \\
.512\end{array}$ & $\begin{array}{l}.3251 \\
.514\end{array}$ & $\begin{array}{l}.3188 \\
.514\end{array}$ & $\begin{array}{l}.3098 \\
.515\end{array}$ \\
\hline $11 \ldots$ & $\left\{\begin{array}{l}A \ldots \\
\alpha\end{array}\right.$ & $\begin{array}{l}.2848 \\
.578\end{array}$ & .2865 & .2997 & 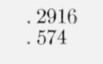 & $\begin{array}{l}.2916 \\
.575\end{array}$ & .2907 & $\begin{array}{l}.2890 \\
.577\end{array}$ & $\begin{array}{l}.2840 \\
.576\end{array}$ & .2757 \\
\hline $12 \ldots$ & $\left\{\begin{array}{l}A \\
\alpha\end{array}\right.$ & $\begin{array}{l}.2388 \\
.665\end{array}$ & $\begin{array}{l}.2396 \\
.665\end{array}$ & .2411 & .2411 & .2411 & $\begin{array}{l}.2403 \\
.663\end{array}$ & $\begin{array}{l}.2388 \\
.664\end{array}$ & $\begin{array}{l}.2358 \\
.662\end{array}$ & .2284 \\
\hline 13. & $\left\{\begin{array}{l}A \ldots \\
\alpha \ldots\end{array}\right.$ & $\begin{array}{l}.1931 \\
.752\end{array}$ & $\begin{array}{l}.1904 \\
.754\end{array}$ & $\begin{array}{l}.1904 \\
.752\end{array}$ & $\begin{array}{l}.1891 \\
.753\end{array}$ & $\begin{array}{l}.1891 \\
.754\end{array}$ & $\begin{array}{l}.1884 \\
.754\end{array}$ & $\begin{array}{l}.1878 \\
.753\end{array}$ & $\begin{array}{l}.1844 \\
.753\end{array}$ & $\begin{array}{l}.1791 \\
.753\end{array}$ \\
\hline 14 & $\left\{\begin{array}{l}A \ldots \\
\alpha \ldots\end{array}\right.$ & $\begin{array}{l}.1209 \\
.890\end{array}$ & $\begin{array}{l}.1163 \\
.889\end{array}$ & $\begin{array}{l}.1135 \\
.888\end{array}$ & $\begin{array}{l}.1124 \\
.888\end{array}$ & .1118 & $\begin{array}{l}.1107 \\
.889\end{array}$ & $\begin{array}{l}.1096 \\
.889\end{array}$ & $\begin{array}{l}.1085 \\
.887\end{array}$ & $\begin{array}{l}.1046 \\
.888\end{array}$ \\
\hline $15 \ldots$ & $\left\{\begin{array}{l}A \ldots \\
\alpha \ldots\end{array}\right.$ & $\begin{array}{l}.0630 \\
1.000\end{array}$ & .0550 & .0501 & .0482 & .0477 & .0467 & .0462 & .0448 & .0429 \\
\hline
\end{tabular}

TABLE 2. Dissociation of 4-chloro-4'-aminodiphenylsulfone $\left(3.747 \times 10^{-5}-M\right)$

\begin{tabular}{|c|c|c|c|c|c|c|c|c|c|}
\hline Solution & $\begin{array}{c}\text { Average } \\
{\left[R^{+}\right]}\end{array}$ & $\begin{array}{l}(1-\alpha) / \alpha \\
{[R] /\left[R^{+}\right]}\end{array}$ & $\begin{array}{l}\text { Molar concen- } \\
\text { tration of } \mathrm{HCl}\end{array}$ & $\begin{array}{l}\text { Corrected } \\
\text { concentration } \\
\text { of hydrogen } \\
\text { ion }\left[\mathrm{H}^{+}\right]\end{array}$ & $\begin{array}{c}\text { Concentration } \\
\text { constant, } K_{c}\end{array}$ & $\begin{array}{c}-\log _{10} K_{c} \\
p K_{c}\end{array}$ & $-\log f=1.0 \mu$ & $\begin{array}{c}p K_{a}=p K_{c}- \\
\quad(-\log f)\end{array}$ & $f$ \\
\hline $\begin{array}{l}1 \\
2 \\
3 \\
4 \\
5\end{array}$ & $\begin{array}{r}0.000 \\
.046 \\
.109 \\
.200 \\
.276\end{array}$ & $\begin{array}{r}20.739 \\
8.174 \\
4.000 \\
2.623\end{array}$ & $\begin{array}{l}2.002 \times 10^{-3} \\
5.005 \\
10.010 \\
15.015\end{array}$ & $\begin{array}{l}2.000 \times 10^{-3} \\
5.001 \\
10.003 \\
15.005\end{array}$ & $\begin{array}{l}\text { 4. } 148 \times 10^{-2} \\
\text { 4. } 088 \\
\text { 4. } 001 \\
\text { 3. } 936\end{array}$ & $\begin{array}{l}\text { 1. } 382 \\
\text { 1. } 388 \\
\text { 1. } 398 \\
1.405\end{array}$ & $\begin{array}{r}0.002 \\
.005 \\
.010 \\
.015\end{array}$ & $\begin{array}{l}\text { 1. } 380 \\
\text { 1. } 383 \\
\text { 1. } 388 \\
1.390\end{array}$ & $\begin{array}{l}1.005 \\
1.012 \\
1.024 \\
1.035\end{array}$ \\
\hline $\begin{array}{l}6 \\
7 \\
8 \\
9 \\
10\end{array}$ & $\begin{array}{l}.336 \\
.391 \\
.440 \\
.479 \\
.513\end{array}$ & $\begin{array}{l}1.976 \\
1.557 \\
1.273 \\
1.087 \\
0.949\end{array}$ & $\begin{array}{l}20.020 \\
25.025 \\
30.030 \\
35.035 \\
40.040\end{array}$ & $\begin{array}{l}20.007 \\
25.010 \\
30.014 \\
35.017 \\
40.021\end{array}$ & $\begin{array}{l}3.953 \\
\text { 3. } 894 \\
3.820 \\
3.806 \\
3.798\end{array}$ & $\begin{array}{l}\text { 1. } 403 \\
\text { 1. } 410 \\
1.418 \\
1.420 \\
1.421\end{array}$ & $\begin{array}{l}.020 \\
.025 \\
.030 \\
.035 \\
.040\end{array}$ & $\begin{array}{l}\text { 1. } 383 \\
\text { 1. } 385 \\
\text { 1. } 388 \\
\text { 1. } 385 \\
1.381\end{array}$ & $\begin{array}{l}1.048 \\
1.059 \\
1.072 \\
1.084 \\
1.097\end{array}$ \\
\hline $\begin{array}{l}11 \\
12 \\
13 \\
14 \\
15\end{array}$ & $\begin{array}{r}.576 \\
.663 \\
.753 \\
.888 \\
1.000\end{array}$ & $\begin{array}{l}.736 \\
.508 \\
.328 \\
.127 \\
.000\end{array}$ & $\begin{array}{r}50.050 \\
70.000 \\
100.000 \\
200.000 \\
500.000\end{array}$ & $\begin{array}{r}50.028 \\
69.975 \\
99.972 \\
199.967\end{array}$ & $\begin{array}{l}\text { 3. } 682 \\
\text { 3. } 555 \\
\text { 3. } 279 \\
2.540\end{array}$ & $\begin{array}{l}\text { 1. } 434 \\
\text { 1. } 449 \\
1.484 \\
1.595\end{array}$ & $\begin{array}{l}.050 \\
.070 \\
.100 \\
.200\end{array}$ & $\begin{array}{l}\text { 1. } 384 \\
\text { 1. } 379 \\
\text { 1. } 384 \\
1.395\end{array}$ & $\begin{array}{l}1.109 \\
1.175 \\
1.259 \\
1.585\end{array}$ \\
\hline
\end{tabular}

$$
K_{a}=K_{\mathrm{c}} \frac{f_{\mathrm{H}_{+}} f_{\mathrm{RNH}_{2}}}{f_{\mathrm{RNH}_{3}}^{+}},
$$

in which the activity coefficients are identified with appropriate subscripts. For simplicity this combined term will henceforth be referred to as $f$. Then

$$
p K_{a}=p K_{c}-\log f .
$$

When the values of $p K_{c}$ are plotted as a function of the ionic strength, $\mu$, a satisfactory extrapolation to the value of $p K_{a}$ can be made. The slope of the line is about 1.0 , as shown in figure 3 . Therefore $-\log f$ may be considered equal to $1.0 \mu$. The values of - $\log f$ may be subtracted from the experimental $p K_{c}$ values to obtain individual $p K_{a}$ values that can be averaged. By this method of calculation $p K_{a}$ is found to be 1.38 , with an estimated uncertainty of 


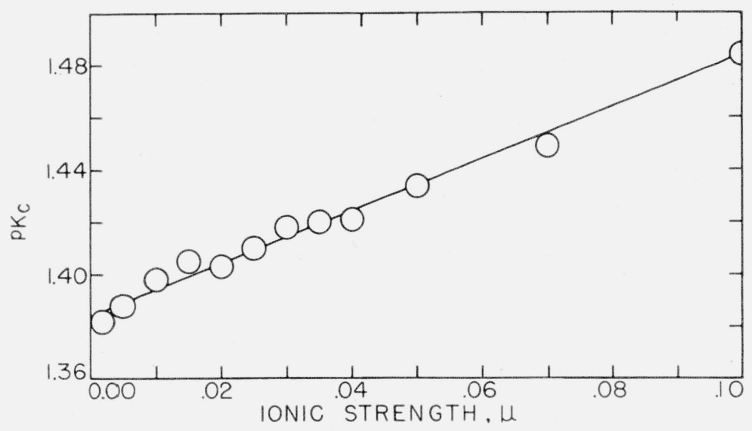

FIGURE 3. $p K_{c}$ values plotted as a function of the ionic strength for extrapolation to $p K_{a}$.

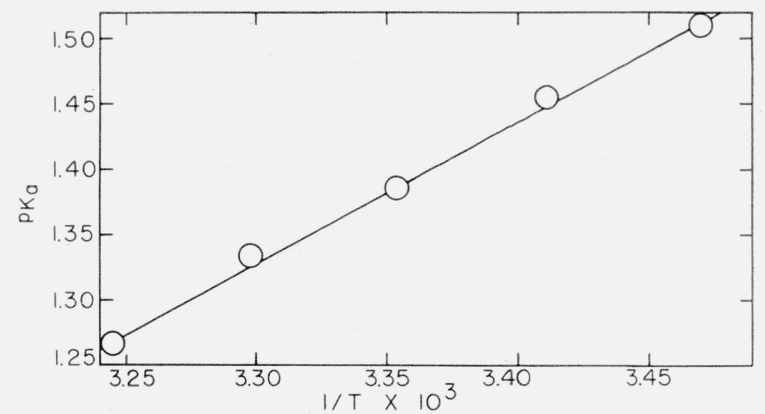

FIGURE 4. $p K_{a}$ values at temperatures from $15^{\circ}$ to $35^{\circ} \mathrm{C}$ plotted as a function of $1 / T$.

TABLE 3. Calculation of $p K_{a}$ from absorbance data at $15^{\circ}$ to $35^{\circ} \mathrm{C}$

\begin{tabular}{|c|c|c|c|c|c|c|c|c|c|c|c|c|}
\hline $\begin{array}{l}\text { Tem- } \\
\text { pera- }\end{array}$ & \multicolumn{4}{|c|}{ A bsorbance at $286 \mathrm{~m} \mu$} & \multicolumn{4}{|c|}{$0.015-M \mathrm{HCl}$} & \multicolumn{4}{|c|}{$0.035-M \mathrm{HCl}$} \\
\hline $\begin{array}{r}{ }^{\circ} \mathrm{C} \\
15 \\
20 \\
25 \\
30 \\
35\end{array}$ & $\begin{array}{c}A_{\mathrm{RNH}_{2}} \\
6.5809 \\
.5993 \\
.5767 \\
.5725 \\
.5654\end{array}$ & $\begin{array}{r}A_{\mathrm{RNH}_{3}^{+}} \\
0.0366 \\
.0410 \\
.0453 \\
.0520 \\
.0575\end{array}$ & $\begin{array}{c}A .015 \mathrm{HCl} \\
0.3968 \\
.4134 \\
.4300 \\
.4407 \\
.4522\end{array}$ & $\begin{array}{c}A .035 \mathrm{HCl} \\
0.2831 \\
.3001 \\
.3224 \\
.3400 \\
.3560\end{array}$ & $\begin{array}{c}(1-\alpha) / \alpha \\
1.957 \\
2.245 \\
2.623 \\
2.949 \\
3.487\end{array}$ & $\begin{array}{c}K_{o} \\
0.0294 \\
.0337 \\
.0393 \\
.0442 \\
.0523\end{array}$ & $\begin{array}{l}p K_{c} \\
1.532 \\
1.472 \\
1.406 \\
1.355 \\
1.281\end{array}$ & $\begin{array}{l}p K_{a} \\
\text { 1. } 517 \\
\text { 1. } 457 \\
\text { 1. } 391 \\
\text { 1. } 340 \\
\text { 1. } 266\end{array}$ & $\begin{array}{c}(1-\alpha) / \alpha \\
0.828 \\
.928 \\
1.090 \\
1.239 \\
1.426\end{array}$ & $\begin{array}{c}K_{c} \\
0.0290 \\
.0325 \\
.0382 \\
.0434 \\
.0499\end{array}$ & $\begin{array}{l}p K_{c} \\
1.538 \\
1.488 \\
1.417 \\
1.363 \\
1.302\end{array}$ & $\begin{array}{l}p K_{a} \\
1.503 \\
1.453 \\
1.382 \\
1.328 \\
1.267\end{array}$ \\
\hline
\end{tabular}

\pm 0.01 at $25^{\circ} \mathrm{C}$. Values of $f$ corresponding to each value of the ionic strength in this series are shown in the last column of the table.

\subsection{Heat of Dissociation}

The heat of dissociation is calculated from the equation

$$
d \log K / d T=\Delta H / 2.303 R T^{2},
$$

in which $\Delta H$ represents the change of molar heat content for the dissociation, $R$ is the gas constant (8.3144 joules $\mathrm{deg}^{-1}$ mole $^{-1}$ ), and $T$ is the temperature in degrees Kelvin (degrees Celsius plus 273.16).

Four solutions in one series, $3.48 \times 10^{-5}-M$ with respect to 4-chloro-4'-aminodiphenylsulfone, were observed throughout the ultraviolet spectral range at five temperatures, namely $15^{\circ}, 20^{\circ}, 25^{\circ}, 30^{\circ}$, and $35^{\circ} \mathrm{C}$. They represented the dissociated state, the undissociated state, and two intermediate stages of dissociation at $0.015-M$ and $0.035-M$ hydrochloric acid concentrations. Absorbance values at the different temperatures, at wavelength $286 \mathrm{~m} \mu$ only, are shown in table 3 . The $K_{c}$ and $p K_{c}$ values are calculated for the two concentrations in the usual manner. In this limited temperature range no significant error is introduced by considering concentrations independent of temperature. Assuming that the same activity coefficient terms $(-\log f=1.0 \mu$ ) apply at the temperature used, which is, of course, not strictly true, $p K_{a}$ values can be estimated from data for the two solutions. They agree within $0.01 p K$ unit at each temperature, so an average is used. A plot of the $p K_{a}$ values against $1 / T \times 10^{3}$, as shown in figure 4 , yields a practically straight line indicating that the beat of dissociation is nearly constant over the temperature range studied. $\Delta \dot{H}$ is found to be approximately 21,000 joules $\mathrm{deg}^{-1}$ mole $^{-1}$. This value is not very different from one of 19,000 reported earlier in a study of 4-aminobenzophenone which was based on more extensive data.

\subsection{Basic Ionization Constant, $K_{b}$}

The basic ionization constant, $K_{b}$, is derived from the usual relationship

$$
K_{b}=K_{w} / K_{a}
$$

in which $K_{w}$ is the activity product of water. For 4chloro- $4^{\prime}$-aminodiphenylsulfone $K_{b}$ is $10^{-14} / 4.2 \times 10^{-2}$ at $25^{\circ} \mathrm{C}$, or $2.4 \times 10^{-13}$. This gives an equivalent value of 12.62 for $p K_{b}$.

\section{References}

[1] Hans Heymann and Louis F. Fieser, J. Am. Chem. Soc. 6\%, 1979 (1945).

[2] Elizabeth E. Sager and Iris J. Siewers, J. Research NBS 45, 489 (1950) RP2162.

[3] Elizabeth E. Sager and Iris J. Siewers, J. Research NBS 49, 7 (1952) RP2337.

[4] Elizabeth E. Sager and Fleur C. Byers, J. Research NBS 58, 33 (1957) RP2731.

Washington, March 19, 1957. 